\title{
Perlindungan Kreditur Atas Pailit Yang Diajukan Debitur Dalam Proses Peninjauan Kembali Di Pengadilan Niaga
}

\author{
Ronald Saija \\ Fakultas Hukum Universitas Pattimura. Ambon, Indonesia \\ E-mail: ronaldreagensaija@gmail.com
}

\begin{abstract}
Legislation Number 34 of 2007 concerning Bankruptcy and Postponement of Obligations of Debt Payments is not fully complete in order to protect the rights of creditors, in connection with the dispute of PT. Golden Adishoes has no clarity about repayment in full if it turns out that the debtor's assets are insolvent is not enough to pay all of his debts, indirectly the creditor is required to accept the fact that all of his debts will not be repaid in full by bankrupt debtors without any actions and what solutions can be made by the creditor before the bankruptcy application is filed by the bankrupt debtor to the Commercial Court.
\end{abstract}

Keywords: Protection, Creditors, Bankruptcy.

\section{A. PENDAHULUAN.}

Kegiatan ekonomi pada umumnya dilakukan oleh pelaku-pelaku ekonomi baik orang perorangan yang menjalankan perusahaan (badan hukum) atau bukan perusahaan (bukan badan hukum). Kegiatan ekonomi pada hakikatnya merupakan kegiatan menjalankan perusahaan yaitu kegiatan yang dimaksud untuk melakukan: ${ }^{1}$

1. Secara terus menerus dalam pengertian tidak terputus-putus;

2. Secara terang-terangan dalam pengertian yang sah;

1 Hartono, Sri Redjeki. (2000). Kapita Selekta Hukum Ekonomi, Bandung: Mandar Maju, h. 4.
3. Kegiatan tersebut dilakukan dalam rangka memperoleh keuntungan untuk diri sendiri atau orang lain.

Kegiatan ekonomi yang terjadi di dalam masyarakat pada hakikatnya adalah rangkaian berbagai perbuatan hukum yang banyak jenis, ragam, kualitas dan variasinya yang dilakukan oleh antar pribadi, antar perusahaan, antar kelompok dan antar negara dalam berbagai volume dengan frekuensi yang tinggi pada setiap saat di berbagai tempat. Peranan tersebut dalam hal mengumpulkan dana dari masyarakat maupun mengeluarkan dana yang 
tersedia untuk membiayai kegiatan perekonomian yang ada. ${ }^{2}$

Mengingat dengan semakin tinggi frekuensi kegiatan ekonomi yang terjadi pada masyarakat tentunya semakin banyak kebutuhan akan dana sebagai salah satu faktor pendorong dalam menggerakkan roda perekonomian. Seiring dengan perkembangan persaingan ekonomi global, maka suatu perusahaan akan dituntut untuk mampu mempertahankan kemampuan keuangannya (finacial), agar tidak terpengaruh oleh dampak adanya krisis global. Apabila perusahaan tidak mampu adaptasi dengan persaingan global, maka tidak sedikit perusahaan akan mengalami kasus pailit atau kebangkrutan.

Suatu perusahaan yang dinyatakan pailit saat ini akan mempunyai imbas dan pengaruh buruk pada seluruh komponen yang ada (global). Oleh karena itu, lembaga kepailitan merupakan salah satu kebutuhan pokok di dalam aktivitas bisnis, karena adanya suatu status pailit merupakan salah stu sebab pelaku bisnis yang keluar dari pasar. Begitu memasuki pasar pelaku bisnis bermain di dalam pasar. Apabila pelaku bisnis sudah tidak mampu lagi untuk bermain di arena pasar, maka dapat keluar dari pasar atau dipaksakan keluar dari pasar. Dalam hal seperti inilah kemudian lembaga kepailitan tersebut berperan. ${ }^{3}$

Salah satu produk hukum yang bertujuan untuk menjamin kepastian, ketertiban, penegakkan dan perlindungan hukum yang berisi keadilan dan kebenaran yang diperlukan saat ini guna mendukung pembangunan perekonomian nasional adalah peraturan mengenai Kepailitan dan Penundaan Kewajiban Pembayaran Utang. ${ }^{4}$ Produk tersebut

2 Siregar, Mustafa. (1990). Efektifitas Perundang-Undangan Perbankan dan Lembaga Keuangan Lainnya, dengan Penelitian di Wilayah Kodya Medan, Disertasi, USU, h. 1.

3 Hartini, Rahayu. (2007). Edisi Revisi Hukum Kepailitan, Malang: UMM Press, h. 3.

4 Budisastra, Aspek Hukum Dalam Kepailitan, http://budisastra.info/home, 2013. adalah Undang-Undang Republik Indonesia Nomor 34 Tahun 2007 tentang Kepailitan dan Penundaan Kewajiban Pembayaran Utang (PKPU). Adapun tujuan dikeluarkan undang-undang tersebut adalah untuk memberikan keseimbangan antara kreditur dan debitur menghadapi masalah kepailitan, memberikan kepastian proses menyangkut waktu, prosedur, tanggungjawab pengeloaan harta pailit dan memudahkan penyelesaian hutang piutang secara cepat, adil, terbuka dan efektif. 5 Selain itu, tujuan dai pengundangan pengundangan undang-undang kepailitan adalah untuk mewujudkan penyelesaian masalah utang piutang secara cepat, adil, terbuka dan efektif. ${ }^{6}$

Istilah "Pailit" pada dasarnya merupaka suatu hal, dimana keadaan debitur (pihak yang berhutang) yang mempunyai dua atau lebih kreditur dan tidak membayar sedikitnya satu utang yang telah jatuh waktu dan dapat ditagih. Berhenti membayar bukan berarti sama sekali tidak membayar, tetapi dikarenakan suatu hal pembayaran akan hutang tersebut tidak berjalan sebagaimana mestinya, jadi apabila debitur mengajukan permohonan pailit, maka debitur tersebut tidak dapat membayar hutang-hutangnya atau tidak mempunyai pemasukkan lagi bagi perusahaannya untuk membayar hutang.

Kepailitan merupakan solusi dari masalah penyelesaian utang debitur yang sedang mengalami kebangkrutan dan bukan sebaliknya bahwa kepailitan justru digunakan sebagai pranata hukum untuk membangkrutkan suatu usaha. Hal ini dikenal dengan prinsip commercial exit

5 Waluyo, Bernadete. (1999). Hukum Kepailitan dan Penundaan Kewajiban Pembayaran Utang, Cetakan Pertama, Bandung: Mandar Maju, h. 5.

$6 \quad$ Widjanarko. (1999). Dampak Implementasi Undang-Undang Kepailitan Terhadap Sektor Perbankan, Jurnal Hukum Bisnis, Yayasan Pengembangan Hukum Bisnis, Vol. 8, h. 73 . 
from financial distress. Kemudahan untuk mempailitkan debitur sebenarnya tidak bertentangan dengan prinsip ini sepanjang kemudahan untuk mempailitkan adalah dalam konteks penyelesaian utang karena adanya kesulitas keuangan (finacial) dari usaha debitur. $^{7}$

Penerapan norma dan prinsip commercial exit from financial distress terhadap kasus kepailitan dikategorikan menjadi dua kelompok. Kelompok pertama adalah putusan yang menerapkan prinsip ini secara benar dan konsisten yakni kepailitan merupakan pranata yang digunakan sebagai jalan keluar terhadap subjek hukum yang sedang mengalami kesulitan keuangan, sehingga menyebabkan tidak dapat memenuhi kewajiban membayar utang-utangnya serta mengakibatkan jumlah utang-utang tersebut melebihi kekayaan perseroan. Sedangkan kelompok kedua adalah putusan pailit yang tidak benar dan tidak konsisten menerapkan commercial exit from financial distress. ${ }^{8}$

Debitur dapat mengajukan permohonan pailit, apabila mempunyai dua atau lebih kreditur yang tidak dapat menjalankan kewajiban yaitu membayar utang beserta bunganya yang telah jatuh tempo. Dalam hal ini, permohonan pailit ditujukan pada Pengadilan Niaga harus mengabulkan, apabila terdapat fakta yang sesuai dengan syarat-syarat untuk dinyatakan pailit telah terpenuhi oleh pihak yang mengajukan pailit. Bagi permohonan pailit yang diajukan debitur sendiri syaratnya adalah debitur tersebut harus mempunyai dua atau lebih kreditur dan tidak membayar sedikitnya satu utang yang telah jatuh tempo.

Syarat debitur dapat dinyatakan pailit, apabila debitur mempunyai dua atau lebih kreditur dan tidak membayar

7 Subhan, M Hadi. (2012). Hukum kepailitan (Prinsip, Norma, dan Praktik di Pradilan), Jakarta: Kencana Pranada Media Group, h. 305.

$$
8 \text { Ibid. }
$$

lunas sedikitnya satu utang yang telah jatuh tempo dan dapat ditagih (ketentuan Pasal 2 ayat (1) Undang-Undang Nomor 37 Tahun 2004). Sedangkan putusan permohonan pernyataan pailit diajukan kepada pengadilan niaga yang daerah hukumnya meliputi daerah tempat kedudukan debitur sebagaimana diatur dalam ketentuan Pasal 3 dan Pasal 4 Undang-Undang Nomor 37 Tahun 2004.

Dalam hal seperti ini, hak-hak sebagai kreditur tidak terlindungi terhadap debitur yang mempunyai itikad tidak baik (itikad buruk). Ada beberapa itikad buruk debitur untuk melepas tanggungjawabnya untuk membayar hutang dengan cara memailitkan diri sendiri, seperti halnya yang terjadi dalam Pengadilan Niaga terdapat praktik-praktik yang menyebabkan lembaga kepailitan tidak berjalan dengan semestinya, Pengadilan Niaga telah digunakan untuk melegitimasikan praktik-praktik tidak membayar utang atau praktik uang yang dibayar menurut kehendak si debitur. Hal ini serupa terjadi pada kasus kepailitan antara PT. Golden Adishoes dengan PT. Bank Negara Indonesia (Persero) Tbk sebagai pihak kreditur. PT. Golden Adishoes mempailitkan diri dikabulkan permohonannya oleh pengadilan niaga melalui putusannya Nomor 33/Pailit/2004/PN. Niaga.Jkt.Pst.

Berdasarkan uraian latar belakang diatas, maka permasalahannya adalah: 1). Apa tujuan debitur mengajukan permohonan kepailitan untuk dirinya sendiri ? 2). Bagaimana upaya hukum bagi kreditur untuk menangkal kepailitan yang diajukan debitur sendiri ?.

\section{B. PEMBAHASAN}

\section{Tujuan Debitur Mengajukan Permohonan Kepailitan Untuk Diri Seindiri.}

Menurut ketentuan Pasal 2 ayat (1) Undang-Undang Nomor 37 Tahun 2004 tentang Kepailitan dan Penundaan 
Kewajiban Pembayaran Utang (selanjutnya disingkat UUKPKPU), permohonan pernyataan pailit terhadap seorang debitur dapat pula diajukan oleh debitur sendiri. Dalam istilah bahasa Inggris "voluntary petition". Kemungkinan yang demikian itu menandakan bahwa menurut UUKPKPU permohonan pernyataan pailit bukan saja dapat diajukan untuk kepentingan para krediturnya, tetapi dapat pula diajukan untuk kepentingan debitur sendiri. ${ }^{9}$

Menurut ketentuan Pasal 2 ayat (1) UUKPKPU, seorang debitur dapat mengajukan permohonan pernyataan pailit terhadap dirinya (voluntary petition) hanya apabila terpenuhi syarat-syarat sebagai berikut:

a. Debitur yang mempunyai dua atau lebih kreditur (lebih dari satu kreditur saja); dan

b. Deitur sedikitnya tidak membayar satu utang yang telah jatuh waktu dan telah dapat ditagih.

Dengan syarat-syarat tersebut dapat diartikan bahwa ketika debitur mengajukan permohonan pernyataan pailit terhadap dirinya, ia harus dapat mengemukakan dan membuktikan memiliki lebih dari satu kreditur. Tanpa dapat membuktikan hal itu, seyogyanya pengadilan dapat menolak permohonan pernyataan pailit tersebut. Debitur harus dapat membuktikan bahwa ia telah tidak membayar salah satu utang krediturnya yang telah jatuh waktu dan telah dapat ditagih.

Menurut penulis lahirnya ketentuan Pasal 2 ayat (1) tersebut dalam rangka untuk lebih memberikan perlindungan hukum kepada kreditur atau para krediturnya dibanding undang-undang Nomor 4 Tahun 1998 dimana terdapat celah hukum yang seringkali dimanfaatkan oleh debitur yang nakal,

9 Sjahdeini, Sutan Remy. (2010). Hukum Kepailitan (Memahami Undang-Undang Nomor 37 Tahun 2004 Tentang Kepailitan, Cetakan IV, Jakarta: Pustaka Utama Grafiti, h.104. sebab di dalam Undang-Undang Nomor 4 Tahun 1998, syaratnya hanya debitur dalam keadaan berhenti membayar, tanpa ada penjelasan lebih lanjut, maka kemudian disalahartikan mestinya untuk debitur yang benar-benar tidak mampu membayar bukan debitur yang tidak mau membayar kemudian minta dijatuhi kepailitan.

Syarat pada nomor 2 (dua) disebut utang yang tidak terbayar adalah utang pokok atau bunganya, sedangkan yang dimaksud dengan "utang yang telah jatuh waktu dan dapat ditagih" menurut penjelasan UUKPKPU adalah kewajiban membayar utang yang telah jatuh waktu, baik telah diperjanjikan karena percepatan waktu penagihannya sebagaimana diperjanjikan, karena pengenaan sanksi atau denda oleh instansi yang berwenang maupun putusan pengadilan, arbiter atau majelis arbitrase. ${ }^{10}$

Dalam kasus PT. Golden Adishoes tersebut permohonan pernyataan pailit sudah sesuai dengan Pasal 89 ayat (1) UU PT. Hal ini diketahui dari Pertimbangan Hukum Hakim Pengadilan Niaga menyatakan bahwa berdasarkan bukti P-17 ternyata Pemohon pada tanggal 2 Agustus 2004 telah melaksanakan RUPS, telah disetujui oleh RUPS bahwa Pemohon agar mempailitkan diri, dengan demikian permohonan Pemohon adalah sah dan legal.

Pembuktian tentang terpenuhinya syarat-syarat kepailitan oleh pemohon pailit ini terlepas dari pembuktian akan adanya persangkaan akan rekayasa yang dilakukan oleh debitor sebagai pemohon pailit. Hal ini bertentangan dengan kompetensi Pengadilan pada umumnya dan Pengadilan Niaga khususnya. Persangkaan akan adanya rekayasa tersebut harus dibuktikan dengan mengajukan gugatan melalui Pengadilan Negeri, yaitu Pengadilan umum yang memutus dan memeriksa perkara perdata

${ }^{10}$ Hartini, Rahayu Op.Cit, h. 28. 
maupun pidana sipil untuk semua golongan penduduk, sedangkan Pengadilan Niaga hanya khusus menangani masalah-masalah kepailitan yang pokok-pokok saja.

Berdasarkan kasus PT. Golden Adishoes tersebut menurut penulis dapat diketahui bahwa dalam kasus tersebut belum pernah dilakukan gugatan ke Pengadilan Negeri mengenai persangkaan akan rekayasa yang dilakukan oleh debitor sebagai pemohon pailit.

Permohonan kepailitan oleh debitor sendiri dapat memungkinkan adanya rekayasa, hal ini sesuai dengan tulisan Mantan Hakim Agung Retnowulan Sutantio yang berjudul Tanggung Jawab Pengurus Perusahaan Debitur Dalam Kepailitan yang mengemukakan kemungkinan terjadinya masalah masalah sebagai berikut: ${ }^{11}$

a) Permohonan pernyataan pailit diajukan oleh seorang pemohon yang telah sengaja telah membuat utang kanan kiri dengan maksud untuk tidak membayar dan setelah itu mengajukan permohonan untuk dinyatakan pailit;

b) Kepailitan diajukan oleh teman baik termohon pailit, yang berkolusi dengan orang atau badan hukum yang dimohon agar dinyatakan pailit, sedangkan alasan yang mendukung permohonan tersebut sengaja dibuat tidak kuat, sehingga jelas permohonan tersebut akan ditolak oleh Pengadilan Niaga. Permohonan ini justru diajukan untuk menghindarkan agar kreditor yang lain tidak bisa mengajukan permohonan kreditor yang lain akan terhambat.

Berkaitan dengan hal adanya persangkaan rekayasa dalam kasus PT. Golden Adishoes, maka Majelis hakim Pengadilan Niaga secara tegas menolak untuk memeriksa perkara PT. Golden Adishoes secara mendetail karena hal ini berkaitan dengan Pengadilan Niaga yang hanya berwenang menyelidiki masalah kepailitan saja, dimana permohonan kepailitan akan dikabulkan selama syarat-syarat permohonan kepailitan secara umum telah dipenuhi oleh pihak pemohon pailit. Menurut penulis hal tersebut sebaiknya diselesaikan di Pengadilan Umum, karena proses pemeriksaan adanya persangkaan rekayasa oleh PT. Golden Adishoes memakan waktu yang lama dan harus disertai oleh bukti-bukti yang kuat, dimana hal tersebut tidak sesuai dengan asas cepat dan efisien Peradilan Niaga dalam menyelesaikan masalah kepailitan.

Apabila permohonan pernyataan pailit yang diajukan debitor adalah suatu rekayasa, namun mengingat sifat pemeriksaan perdata adalah formal dan sepanjang syarat-syaratnya telah terpenuhi, apalagi mengingat ketentuan Pasal 8 ayat (4) UUKPKPU yang menentukan permohonan pernyataan pailit harus dikabulkan apabila terdapat fakta-fakta yang terbukti secara sederhana bahwa persyaratan untuk dinyatakan pailit sebagaimana dimaksud Pasal 2 ayat (1) telah terpenuhi, maka dapat dinyatakan sulit bagi hakim untuk tidak mengabulkan permohonan tersebut.

Lebih lanjut ketentuan Pasal 8 ayat (1) UUKPKPU menyatakan, bahwa dalam hal permohonan pernyataan pailit yang diajukan debitor tidak diwajibkan bagi pengadilan untuk memanggil para kreditor, pengadilan hanya wajib memanggil debitor dalam hal permohonan pernyataan pailit yang diajukan oleh kreditor, Kejaksaan, Bank Indonesia, Bapepam dan Menteri Keuangan. Mengingat juga ketentuan UU Kepailitan yang tidak mengharuskan dilakukan pemberitahuan secara terbuka kepada publik mengenai pengajuan permohonan pernyataan pailit itu, maka rekayasa yang dilakukan oleh debitor

11 Sjahdeini, Sutan Remy. Op. Cit. h. 12. 
tersebut secara mudah dapat dilakukan oleh debitor yang nakal.

Menurut penulis kasus PT. Golden Adishoes yang mempailitkan diri merupakan langkah terbaik untuk menyelesaikan kewajiban pembayaran utang terhadap para kreditornya. PT. Golden Adishoes yang semula diprediksikan akan berjalan sesuai dengan Business forecasting/planning ternyata dalam perjalanannya tidak sesuai dengan harapannya tersebut. Kondisi keuangan perusahaan yang cukup parah akibat berbagai macam penyebab baik internal maupun eksternal, menyebabkan perusahaan tidak dapat beroperasi secara optimal dan bahkan untuk membayar pengeluaran tetap (fix cost) dan biaya operasi yang dikeluarkan untuk mengoperasikan suatu sistem atau menjalankan sebuah sistem (operation cost) saja sudah tidak mampu apalagi untuk memenuhi pembayaran utang-utangnya. Hal itu terlihat dari pertimbangan hukum dalam kasus PT. Golden Adishoes oleh Hakim Pengadilan Niaga yang mempertimbangkan bahwa alasan pemohon tersebut terbukti dari bukti P-16 (Laporan Appraisal tanggal 20 Pebruari 2004). Harapan untuk recovery ke depan juga tidak ada mengingat jumlah utang sudah jauh melebihi jumlah aset. Dalam kondisi yang seperti ini maka secara teknis, perusahaan sudah dalam kebangkrutan (technical bankruptcy). Di sinilah fungsi pranata kepailitan sebagai jalan keluar secara komersial untuk menyelesaikan kewajiban pembayaran utang terhadap kreditornya. Dalam situasi seperti ini, maka konsep mempermudah kepailitan harus diterapkan bukan sebaliknya.

Menurut Penulis, sangat disayangkan UUKPKPU tidak menentukan agar pengadilan dapat memutuskan pailit seorang debitor haruslah putusan tersebut diambil atas dasar persetujuan para kreditor mayoritas. Hal ini terlihat jelas dalam kasus pailitnya PT. Golden Adishoes, dimana para kreditor yaitu PT Bank Negara Indonesia, Citibank N.A, Supplier Korea dan Supplier Lokal tidak dimintai persetujuan terlebih dahulu oleh PT. Golden Adishoes dalam rangka mengajukan permohonan kepailitan. Pada dasarnya hal ini harus dilakukan karena PT. Golden Adishoes selaku debitor dan para kreditor terikat suatu perjanjian utang piutang, sehingga dalam memutuskan suatu masalah yang menyangkut kedua belah pihak, harus mendapat persetujuan yang lain, apalagi harta kekayaan debitor tidak mencukupi untuk membayar semua hutang dengan demikian kreditor jelas dirugikan dalam hal ini. Secara tidak langsung hal tersebut tidak sesuai dengan KUHPerdata Pasal 1338, suatu perjanjian harus dilakukan dengan itikad yang baik dan prinsip dari tujuan hukum kepailitan itu sendiri, yaitu memberikan keadilan dalam hal pengembalian hutang debitor kepada kreditor secara sama.

Sekalipun dalam UUKPKPU memperbolehkan permohonan pernyataan pailit diajukan oleh debitor namun demi kepentingan para kreditor lain sesuai asas keseimbangan (menurut besar kecilnya piutang) haruslah mendapat persetujuan dari para kreditornya. UUKPKPU seyogianya menentukan putusan pengadilan atas permohonan pernyataan pailit oleh debitor harus berdasarkan persetujuan semua kreditor atau mayoritas kreditor. Mayoritas kreditor yang dimaksudkan adalah para kreditor pemilik sebagian besar piutang. Untuk menentukan mayoritas tersebut lebih dari 50\% dari jumlah utang debitor atau dua pertiga atau tiga perempat dari jumlah utang debitor.

Menurut Penulis, apa yang dikemukakan ini mungkin benar, karena jelas bahwa Mahkamah Agung dalam taraf kasasi telah tidak mempertimbangkan alasan-alasan kasasi, secara tuntas dan hanya secara umum dan sangat sumir mengemukakan bahwa 
Pengadilan Niaga telah tidak salah menerapkan hukum. Selain itu alasan-alasan kasasi sama sekali tidak dipertimbangkan, yang menurut Pemohon Kasasi telah disampaikan, sama sekali tidak dimuat dalam putusan kasasi dan jadinya sama sekali tidak dipertimbangkan.

Menurut Penulis, Mahkamah Agung dalam taraf PK juga dengan pendek menyatakan, bahwa tidak ada kesalahan berat dalam penerapan hukum yang dilakukan oleh Pengadilan Niaga dan oleh Majelis tingkat kasasi, sehingga permohonan PK harus ditolak. Disamping tujuan debitor mengajukan permohonan kepailitan untuk dirinya sendiri yang telah diuraikan di atas, menurut Penulis tujuan mempailitkan diri dari debitor antara lain adalah:

a. Ada indikasi menyembunyikan hartanya dan supaya tidak membayar bunga lebih banyak lagi.

b. Adanya rasa malu dari pihak debitor jika dipailitkan oleh pihak lain, sehingga debitor memutuskan mengajukan pailit untuk dirinya sendiri.

\section{Upaya Hukum Bagi Kreditur Untuk Menangkal Kepailitan Yang Diajukan Debitur Sendiri.}

\section{Pengajuan PKPU oleh Kreditur kepada Debitur.}

Penundaan Kewajiban Pembayaran Utang (PKPU) diatur dalam Bab Ketiga yaitu dalam Pasal 222 sampai dengan Pasal 294 UU No. 37 Tahun 2004 tentang Kepailitan Dan Penundaan Kewajiban Pembayaran Utang. Permohonan Penundaan Kewajiban Pembayaran Utang dilakukan dengan maksud untuk mengajukan Rencana Perdamaian yang meliputi tawaran pembayaran sebagian atau seluruh utang kepada kreditur. Pasal 222 UUK dan PKPU menentukan bahwa: a. Penundaan Kewajiban Pembayaran Utang diajukan oleh Debitur yang mempunyai lebih dari 1 (satu) Kreditur atau oleh Kreditur,

b. Debitur yang tidak dapat atau memperkirakan tidak akan dapat melanjutkan membayar utang-utangnya yang sudah jatuh waktu dan dapat ditagih, dapat memohon penundaan kewajiban pembayaran utang, dengan maksud untuk mengajukan rencana perdamaian yang meliputi tawaran pembayaran sebagian atau seluruh utang kepada Kreditur,

c. Kreditur yang memperkirakan bahwa Debitur tidak dapat melanjutkan membayar utangnya yang sudah jatuh waktu dan dapat ditagih, dapat memohon agar kepada Debitur diberi penundaan kewajiban pembayaran utang, untuk memungkinkan Debitur mengajukan rencana perdamaian yang meliputi tawaran pembayaran sebagian atau seluruh utang kepada Krediturnya.

Menurut Pasal 222 ayat (1) dan ayat (3) UUK-PKPU, dapat diketahui bahwa PKPU dapat diajukan oleh kreditor juga selain oleh debitor. Dengan kata lain, PKPU dapat diajukan baik oleh debitor maupun oleh kreditor. Hak kreditor untuk mengajukan PKPU menurut UUK-PKPU sejalan dengan ketentuan Chapter 11 dari US Bankruptcy Code, bukan hanya debitor yang diberi hak untuk mengajukan permohonan untuk diadakan reorganization, tetapi juga hak itu diberikan kepada kreditor.

Berdasarkan Pasal 222 ayat (2), maka menurut penulis tolok ukur bagi kreditor dalam menentukan bahwa debitor "diperkirakan tidak akan dapat melanjutkan membayar utang-utangnya yang sudah jatuh waktu dan dapat di tagih "harus berdasarkan financial audit 
dan analisis keuangan yang dilakukan oleh suatu akuntan publik. Bukan berdasarkan pertimbangan subjektif dari kreditor semata. Bagi bank-bank pemberi kredit, selalu memperjanjikan di dalam perjanjian kredit agar debitor menyerahkan secara periodik kepada kreditor laporan keuangan debitor yang telah diaudit oleh akuntan publik. Kewajiban tersebut terutama dibebankan kepada debitor yang memperoleh kredit besar, bukan kepada debitor UKM. Bagi debitor yang berbentuk perseroan terbatas, penyerahan laporan keuangan yang diaudit oleh akuntan publik tidak merupakan masalah karena menurut undang-undang tentang perseroan terbatas, perseroan terbatas harus menunjuk akuntan publik guna melakukan pemeriksaan terhadap laporan keuangannya. Bagi perusahaan yang sudah tercatat sahamnya di bursa efek. Undang-undang pasar modal juga menentukan hal yang demikian. Ketentuan tersebut adalah demi kepentingan para pemegang saham perusahaan tersebut.

Berdasarkan ketentuan Pasal 222 UUK dan PKPU ini dapat diartikan, yang dimaksud dengan penundaan kewajiban pembayaran utang pada umumnya adalah untuk mengajukan rencana perdamaian yang meliputi tawaran pembayaran seluruh atau sebagian utang kepada kreditur konkuren, sedangkan tujuannya adalah untuk kreditur konkuren, sedangkan tujuannya adalah untuk memungkinkan seorang debitur meneruskan usahanya meskipun ada kesukaran pembayaran dan untuk menghindari kepailitan.

\section{Pengajuan Kasasi dan Peninjauan Kembali Oleh Kreditor Atas Putusan Pailit Debitor.}

Dalam kepailitan tidak dikenal upaya hukum banding, akan tetapi terhadap putusan atas permohonan pernyataan pailit, upaya hukum yang dapat dilakukan adalah Kasasi dan Peninjauan Kembali (PK). Pemangkasan upaya hukum banding, dikonstruksikan untuk memangkas jalur kepailitan ini. Dengan tidak adanya upaya hukum banding, maka jalur acara kepailitan lebih cepat dibandingkan dengan jalur acara perdata biasa. Konstruksi upaya hukum demikian sangat baik mengingat lembaga upaya hukum ini sering hanya digunakan oleh pihak yang berkepentingan untuk mengulur waktu proses beracara sehingga meskipun pihak yang bersangkutan sudah merasa akan kalah ia akan tetap melakukan upaya hukum di mana pemenuhan putusan hakim bisa diulur waktunya.

Pada sisi lain, tidak jarang ditemukan dari kepentingan advokad itu sendiri yang sering menggiring kliennya untuk terus melakukan segala upaya hukum yang tersedia. Kepentingan advokat tersebut tentunya erat berkait dengan persoalan keuntungan ekonomis, di mana jika semakin banyak upaya hukum yang ditempuh, maka keuntungan ekonomis yang didapat juga semakin banyak dari kliennya. Selain itu, hakikat pengadilan tingkat banding adalah sama dengan pengadilan tingkat pertama. Keduanya sama-sama sebagai pengadilan judex factie. Dengan demikian cenderung terjadinya overlaping antara pengadilan tingkat pertama dengan pengadilan tingkat banding. Sehingga adanya pengadilan tingkat banding tidak memberikan sebuah nilai tambah bagi para pencari keadilan (justiabelen), karena itu lebih baik dihilangkan saja dalam suatu proses peradilan. ${ }^{12}$

Menurut M. Hadi Shubhan sebenarnya yang dihilangkan tidak hanya upaya hukum banding saja, melainkan upaya hukum luar biasa yang berupa peninjauan kembali juga selayaknya untuk dihapuskan. ${ }^{13}$

Setelah Pengadilan Niaga menjatuhkan putusan atas permohonan

12 Shubhan, M. Hadi. Op. Cit, h. 127.

13 Ibid. 
pernyataan pailit, maka upaya hukum yang dapat diajukan terhadap putusan tersebut adalah kasasi ke Mahkamah Agung (Pasal 11 ayat (1) UUKPKPU). Dalam UU Kepailitan juga menentukan alasan yang dapat digunakan untuk mengajukan peninjauan kembali secara limitatif. Dalam Pasal 295 ayat (2) UUKPKPU, ditentukan alasan atau syarat yang dapat digunakan untuk mengajukan permohonan peninjauan kembali, antara lain:

a) Apabila yang dijadikan dasar peninjauan kembali berupa bukti baru, maka waktu yang diberikan adalah 180 hari setelah tanggal putusan yang dimohonkan peninjauan kembali memperoleh kekuatan hukum tetap.

b) Apabila yang dijadikan dasar peninjauan kembali berupa kekeliruan yang nyata, maka waktu yang diberikan adalah 30 hari setelah tanggal putusan yang dimohonkan peninjauan kembali memperoleh kekuatan hukum tetap.

Proses permohonan peninjauan kembali atas putusan pernyataan pailit hampir sama dengan proses permohonan kasasi di mahkamah agung. Permohonan peninjauan kembali diatur dalam Pasal 296 sampai Pasal 298 UU Kepailitan. Berdasarkan studi kasus kepailitan yang diajukan oleh pihak debitor sendiri terdapat upaya dari pihak kreditor untuk menangkis tindakan debitor yang mempailitkan diri tersebut melalui upaya kasasi.

UUKPKPU Ketentuan mengenai pihak yang dapat mengajukan kasasi ini. Dalam Pasal 11 Ayat (3) dikatakan bahwa permohonan kasasi selain dapat diajukan oleh debitor dan kreditor yang merupakan pihak pada persidangan tingkat pertama, juga dapat diajukan oleh kreditor lain yang bukan merupakan pihak pada persidangan tingkat pertama yang tidak puas terhadap putusan atas permohonan pernyataan pailit. Ketentuan ini merupakan terobosan baru dalam hukum acara karena dalam hukum acara peradilan apa pun di Indonesia tidak diperkenankan yang bukan pihak dalam tingkat pertama bisa mengajukan permohonan kasasi ini.

Ketentuan pihak kreditor yang bukan para pihak, pada satu sisi merupakan salah satu bentuk perlindungan hukum terhadap para kreditor dari debitor pailit. Dikatakan sebagai bentuk perlindungan hukum bagi kreditor tersebut karena adanya kemungkinan permohonan pailit diajukan oleh kreditor yang mempunyai piutang yang kecil namun ia mengajukan permohonan pailit, di mana aset debitor pailit jauh melebihi dari kreditor kecil yang mengajukan pailit tersebut. Hal ini potensi untuk merugikan kreditor besar karena kepailitan yang tidak proporsional antara aset dengan utang cenderung merugikan debitor itu sendiri dari kreditor besarnya. Menurut penulis upaya hukum yang dilakukan oleh pihak kreditur dengan mengajukan kasasi dan Peninjauan Kembali merupakan upaya untuk mencegah agar debitor tidak menjadi pailit.

\section{PE N U T U P}

Tujuan debitor mengajukan permohonan kepailitan untuk dirinya sendiri adalah untuk menghindar dari pemenuhan kewajiban pembayaran utang dan bunga pinjaman yang disebabkan karena perusahaan (debitor) mengalami kesulitan keuangan sehingga menyebabkan perusahaan tidak mampu lagi memenuhi kewajiban-kewajiban pembayaran utangnya serta tidak ada harapan lagi untuk melanjutkan usaha perusahaan (debitor) yang dikarenakan beban utang sudah jauh melebihi dari aset perusahaan itu sendiri. Di samping itu upaya debitor mempailitkan diri adalah sebagai upaya terakhir (ultimum 
remidium) yang menurut pihak debitor paling fair untuk semua pihak untuk menyelesaikan hutang-hutang Pemohon/Termohon (debitor), karena dengan pailit maka pembayaran hutang-hutang Pemohon/Termohon (debitor) tersebut dapat dilakukan dengan tertib secara seimbang (pari passu) oleh Kurator yang independen dengan diawasi oleh Hakim Pengawas serta dapat dicegah berkurangnya jumlah harta debitor (harta pailit) di samping itu pengamanan harta pailit dapat terjamin dan dapat dihindari kemerosotan nilai harta pailit secara terus menerus akibat Pemohon/Termohon (debitor) berhenti beroperasi.

Upaya Hukum Bagi Kreditor Untuk Menangkal Kepailitan yang Diajukan Debitor Sendiri adalah dengan melakukan Permohonan Penundaan Kewajiban Pembayaran Utang dan upaya hukum (kasasi dan peninjauan kembali). Permohonan Penundaan Kewajiban Pembayaran Utang oleh Kreditur kepada debiturnya adalah agar debitur yang berada dalam keadaan insolvensi, mempunyai kesempatan untuk mengajukan suatu Rencana Perdamaian, baik berupa tawaran untuk pembayaran utang secara keseluruhan ataupun sebagian atas utangnya, dengan jalan melakukan restrukturisasi (penjadwalan ulang) atas utang-utangnya. Upaya hukum (kasasi dan peninjauan kembali) di lakukan oleh pihak kreditur dilakukan dengan tujuan pihak debitor tidak dalam keadaan pailit agar kepentingan kreditor dapat terlindungi.

\section{DAFTAR PUSTAKA}

Hartono, Sri Redjeki. (2000). Kapita Selekta Hukum Ekonomi, Bandung: Mandar Maju.

Hartini, Rahayu. (2007). Edisi Revisi Hukum Kepailitan, Malang: UMM Press.
Sjahdeini, Sutan Remy. (2010). Hukum Kepailitan (Memahami Undang-Undang Nomor 37 Tahun 2004 Tentang Kepailitan, Cetakan IV, Jakarta: Pustaka Utama Grafiti.

Subhan, M Hadi. (2012). Hukum kepailitan (Prinsip, Norma, dan Praktik di Pradilan), Jakarta: Kencana Pranada Media Group.

Waluyo, Bernadete. (1999). Hukum Kepailitan dan Penundaan Kewajiban Pembayaran Utang, Cetakan Pertama, Bandung: Mandar Maju.

\section{Lain-Lain}

Siregar, Mustafa. (1990). Efektifitas Perundang-Undangan Perbankan dan Lembaga Keuangan Lainnya, dengan Penelitian di Wilayah Kodya Medan, Disertasi, USU.

Widjanarko. (1999). Dampak Implementasi Undang-Undang Kepailitan Terhadap Sektor Perbankan, Jurnal Hukum Bisnis, Yayasan Pengembangan Hukum Bisnis, Vol. 8.

Budisastra, Aspek Hukum Dalam Kepailitan, http://budisastra.info / home. 